\title{
Effect of sintering temperature on density, hardness and tool wear for
} alumina-zirconia cutting tool

\author{
A.B Hadzley ${ }^{* 1}$, T. Norfauzi ${ }^{2}$, , U.A.A Umar ${ }^{2}$, A.A. Afuza ${ }^{1}$, M.M. Faiz ${ }^{1}$ and M.F. Naim ${ }^{1}$ \\ ${ }^{1}$ Precision Machining Group, Advanced Manufacturing Centre, \\ Faculty of Manufacturing Engineering, Universiti Teknikal Malaysia Melaka, \\ Hang Tuah Jaya, 76100 Durian Tunggal, Melaka, MALAYSIA. \\ Email:*hadzley@utem.edu.my \\ ${ }^{2}$ Faculty of Mechanical and Manufacturing Engineering Technology, \\ Universiti Teknikal Malaysia Melaka, \\ Hang Tuah Jaya, 76100 Durian Tunggal, Melaka, MALAYSIA.
}

\begin{abstract}
Combination of alumina $\left(\mathrm{Al}_{2} \mathrm{O}_{3}\right)$ and zirconia $\left(\mathrm{ZrO}_{2}\right)$ as cutting tool have been established themselves as a dominant in ceramic category for dry machining. The mechanical properties of $\mathrm{Al}_{2} \mathrm{O}_{3}-\mathrm{ZrO}_{2}$ cutting tool were critically dependent on its density and hardness, which affected by the powder preparation and sintering processes. This paper present the effect of sintering temperature on density, hardness and tool wear of $\mathrm{Al}_{2} \mathrm{O}_{3}-\mathrm{ZrO}_{2}$ cutting tool. Specific composition of 80-90 wt $\% \mathrm{Al}_{2} \mathrm{O}_{3}$ and $10-20 \mathrm{wt} \% \mathrm{ZrO}_{2}$ powders were mixed and ball milled for 12 hours. These powders then were compacted in the form of RNGN120600 designated cutting tool by using manual hydraulic press before undergone secondary compaction by Cold Isostatic Press. The compacted powders then were sintered from $1200^{\circ} \mathrm{C}$ to $1400^{\circ} \mathrm{C}$ at constant 9 hours soaking time. For each sintered cutting tool, evaluation has been made based on the density and hardness. By using AISI 1045 as a workpiece material, the wear performance of the selected cutting tools were evaluated within $200-350 \mathrm{~m} / \mathrm{min}$ cutting speeds, $0.1 \mathrm{~mm} / \mathrm{rev}$ feed rate and $0.5 \mathrm{~mm}$ depth of cut. The results shows that the sintering temperature at $1400^{\circ} \mathrm{C}$ and 9 hours soaking time produced maximum relative density and hardness for $90 \mathrm{wt} \% \mathrm{Al}_{2} \mathrm{O}_{3}$ and $10 \mathrm{wt} \% \mathrm{ZrO}_{2}$ at $94.17 \%$ and $63.4 \mathrm{HRC}$ respectively. Cutting tool contained with $80 \mathrm{wt} \% \mathrm{Al}_{2} \mathrm{O}_{3}$ and $20 \mathrm{wt} \% \mathrm{ZrO}_{2}$ contributed maximum relative density of $97 \%$ and hardness of 70.07 HRC. Maximum tool life recorded was $156 \mathrm{~s}$ at $200 \mathrm{~m} / \mathrm{min}$ cutting speed. Wear mechanisms of fabricated cutting tool dominated by the notch and flank wear at the early stage of machining and formation built up edge at the end of machining process.
\end{abstract}

Keywords: Alumina; zirconia; cutting tool; sintering; hardness; density; machining; tool wear. 


\section{INTRODUCTION}

Production through processes such as casting, forming and forging method require an additional process which is a machining as finishing process [1-2]. In machining process, selection of appropriate cutting tool is important to create products with high dimensional accuracy and fine surface finish [3-4]. The properties of the cutting tool such as Alumina $\left(\mathrm{Al}_{2} \mathrm{O}_{3}\right)$ that possess high hardness, high wear resistance and excellent abrasion resistance would be beneficial in machining hard materials [5]. According to Varaprasad et al.[6], $\mathrm{Al}_{2} \mathrm{O}_{3}$ based cutting tools are more inert than high speed steel and carbide cutting tools at high temperatures, which make this cutting tool ideal for machining with high cutting speed. Another advantage of using $\mathrm{Al}_{2} \mathrm{O}_{3}$ cutting tool is that it does not require cooling fluids to reduce the cutting temperature that provide more towards sustainable machining [7-8].

Even though $\mathrm{Al}_{2} \mathrm{O}_{3}$ possess holistic characteristic with its excellent properties, $\mathrm{Al}_{2} \mathrm{O}_{3}$ also has its weakness such as lack of toughness and brittleness. This deficiency gives a bad impression in the early machining as the brittleness could causes premature chipping at the edge of cutting tools [9-10]. This weakness can be improved by adding secondary material like Zirconia $\left(\mathrm{ZrO}_{2}\right)$ [11-12]. According to a study conducted by the Vasudevan et al. (2012) [13], reinforcement $\mathrm{ZrO}_{2}$ into $\mathrm{Al}_{2} \mathrm{O}_{3}$ matrix associated with the several factors such particles size and shape as well as the stability of $\mathrm{ZrO}_{2}$ phases. The addition of $\mathrm{ZrO}_{2}$ in $\mathrm{Al}_{2} \mathrm{O}_{3}$ structure would yield toughening phase transformation by interfering microcrack generation from continuing to spread, especially at the grain boundary [14-15].

In the past, the development of $\mathrm{Al}_{2} \mathrm{O}_{3}-\mathrm{ZrO}_{2}$ cutting tools have been explored by the several authors [16-19]. Szutkowska et al. [16] evaluated the different properties of cutting tools that fabricated based on pure $\mathrm{Al}_{2} \mathrm{O}_{3}, \mathrm{Al}_{2} \mathrm{O}_{3}-\mathrm{ZrO}_{2}$ composite with unstabilized and stabilized $\mathrm{ZrO}_{2}, \mathrm{Al}_{2} \mathrm{O}_{3}-\mathrm{ZrO}_{2}$ composite with addition of $\mathrm{TiC}$ and $\mathrm{Al}_{2} \mathrm{O}_{3}-\mathrm{Ti}(\mathrm{C}, \mathrm{N})$ composite with $2 \mathrm{wt} \%$ of $\mathrm{ZrO}_{2}$. The author compared their performance mainly based on the fracture toughness, young modulus, hardness and density. The authors found that maximum fracture toughness obtained by the cutting tool that composed with $\mathrm{Al}_{2} \mathrm{O}_{3}$ with stabilized and unstabilized $\mathrm{ZrO}_{2}$. The author proposed that the addition of $\mathrm{ZrO}_{2}$ with improve the fracture toughness with toughening mechanism at the grain boundary.

Another study conducted by Zahirani et al. [17] focused on the effect of Magnesium Oxide (MgO) on $\mathrm{Al}_{2} \mathrm{O}_{3}-\mathrm{ZrO}_{2}$ cutting tool. Specific composition of $\mathrm{Al}_{2} \mathrm{O}_{3}$, Ytria Stabilized Zirconia (YSZ) and $\mathrm{MgO}$ were mixed and uniaxial pressed into the shape of cutting tool. Density and microstructure were evaluated based on the variant content of $\mathrm{MgO}$. The author found that the addition of $\mathrm{MgO}$ improved the density and hardness of $\mathrm{Al}_{2} \mathrm{O}_{3}-\mathrm{ZrO}_{2}$ cutting tool and controlled the grain size of $\mathrm{Al}_{2} \mathrm{O}_{3}$. With addition of $\mathrm{MgO}$, the wear performance increased up to 50\% when machining with AISI 1018.

Singh et al. (2016) [18] investigated the microstructure and machining parameter optimization of $\mathrm{Al}_{2} \mathrm{O}_{3}$ and $\mathrm{ZrO}_{2}$ that doped with $\mathrm{Cr}_{2} \mathrm{O}_{3}$. The author performed hardness and fracture toughness evaluation to assess the properties of the cutting tool. The authors also evaluated the performance of the fabricated cutting tool based on the flank wear, cutting force and surface roughness. The results present that combination of $\mathrm{Al}_{2} \mathrm{O}_{3}, \mathrm{ZrO}_{2}$ and $\mathrm{Cr}_{2} \mathrm{O}_{3}$ capable to perform at very high cutting speed. The author propose that formulation of cutting tools in their study have great potential to replace carbide or coated carbide.

Recently, Sabuan et al. [19] developed ceramic cutting insert with combination of $\mathrm{Al}_{2} \mathrm{O}_{3}, \mathrm{ZrO}_{2}$ and Copper $(\mathrm{Cu})$. The author focused on the hardness, density, shrinkage and 
microstructure to assess the compatibility of these particles. The author performed uniaxial press to compact the powders in the form of diamond shape insert. The authors found that addition of $\mathrm{Cu}$ improving density of $\mathrm{Al}_{2} \mathrm{O}_{3}-\mathrm{ZrO}_{2}$ structure at the sintering temperature of $1000^{\circ} \mathrm{C}$. However, when the sintering temperature increased to $1300^{\circ} \mathrm{C}$, the structure of $\mathrm{Cu}$ exhibited phase change which diminished the hardness of composition.

While most of the previous study to develop $\mathrm{Al}_{2} \mathrm{O}_{3}-\mathrm{ZrO}_{2}$ cutting tools were focused more into the effect of tertiary phase on the mechanical properties, the characteristics of $\mathrm{Al}_{2} \mathrm{O}_{3}-\mathrm{ZrO}_{2}$ particles at the sintering level still did not get much attention. In this study, series of fabrication of $\mathrm{Al}_{2} \mathrm{O}_{3}-\mathrm{ZrO}_{2}$ cutting tool were implemented. Focus on the variation sintering temperature, the fabricated cutting tool have been tested on density and hardness where the analysis of particles characteristics during sintering have been discussed. Further, the $\mathrm{Al}_{2} \mathrm{O}_{3}-$ $\mathrm{ZrO}_{2}$ cutting tool have been tested in machining trials at various cutting speed. The wear mechanism for selected cutting tool have been assessed to further understand the characteristics of $\mathrm{Al}_{2} \mathrm{O}_{3}-\mathrm{ZrO}_{2}$ partnership in high stress and temperature application. This study is aimed to further investigate the properties of cutting tool that developed from the author's previous works [32]. This hopefully will provide better understanding regarding characteristic of $\mathrm{Al}_{2} \mathrm{O}_{3}$ and $\mathrm{ZrO}_{2}$ particles for wear and tribology application.

\section{METHODOLOGY AND MATERIALS}

\section{Fabrication of Cutting Tool}

Specific weight $\mathrm{Al}_{2} \mathrm{O}_{3}$ and $\mathrm{ZrO}_{2}$ powders were prepared carefully with addition of Polyethylene glycol (PEG) binder in mixed in the ball mill at 12 hours. The powders were then compacted using manual hydraulic before secondary compaction using Cold Isostatic Press in the form of RNGN120600 designated cutting tool. Sintering process were held at the variant temperature from $1200^{\circ} \mathrm{C}$ to $1400^{\circ} \mathrm{C}$ with constant soaking time at 9 hours. For each sintered sample, the density and hardness were measured by using electronic density testing machine and Rockwell hardness tester, with refer to $3.96 \mathrm{~g} / \mathrm{cm}^{3}$ as an ideal density of $\mathrm{Al}_{2} \mathrm{O}_{3}$. Figure 1 show the sequence of process flow used to fabricate the cutting tool. Table 1 shows the processing parameter used for preparation of $\mathrm{Al}_{2} \mathrm{O}_{3}-\mathrm{ZrO}_{2}$ cutting tool.

Table 1. Processing parameters to fabricate $\mathrm{Al}_{2} \mathrm{O}_{3}-\mathrm{ZrO}_{2}$ cutting tool

\begin{tabular}{ll}
\hline Composition & $90 \mathrm{wt} \% \mathrm{Al}_{2} \mathrm{O}_{3}$ and $10 \mathrm{wt} \% \mathrm{ZrO}_{2}$ \\
Ball Mill & $12 \mathrm{hours}$ \\
Sintering Temperature & $1200^{\circ} \mathrm{C}-1400^{\circ} \mathrm{C}$ with 9 hours soaking time \\
CIP Pressure & $300 \mathrm{MPa}$ \\
\hline
\end{tabular}




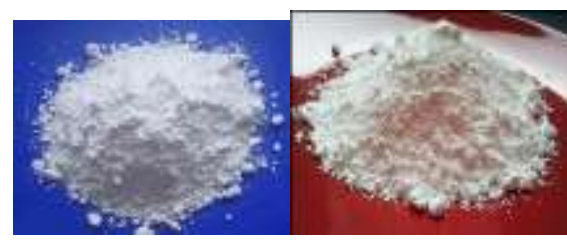

(a)

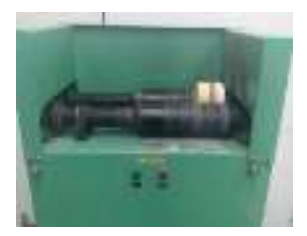

(b)

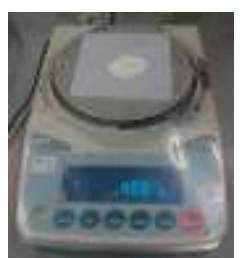

(c)

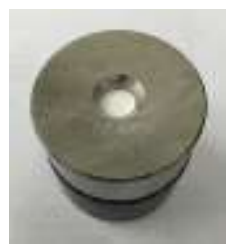

(d)

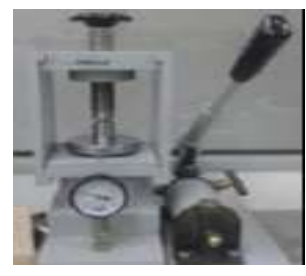

(e)

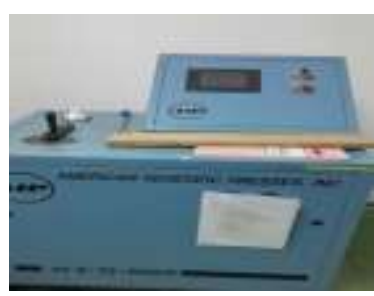

(f)

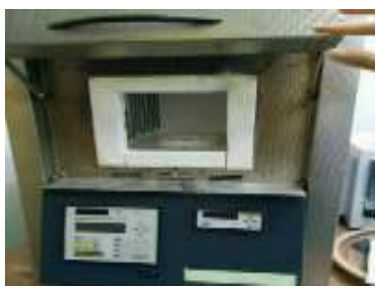

$(\mathrm{g})$

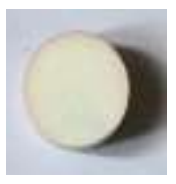

(h)

Figure 1. The procedure to fabricate $\mathrm{Al}_{2} \mathrm{O}_{3}-\mathrm{ZrO}_{2}$ cutting tool (a) Preparing $\mathrm{Al}_{2} \mathrm{O}_{3}$ and $\mathrm{ZrO}_{2}$ powders (b) Ball milling for 12 hours (c) Weighting of powders (d) Inserting powders into the mould (e) Pressing the powders by hydraulic press (f) Pressing the powders by Cold Isostatic Press (g) Sintering the compacted powders (h) Finish product of ceramic cutting tool.

\section{Optimum Content of Zirconia}

As the optimum sintering temperature determined, the weight of $\mathrm{Al}_{2} \mathrm{O}_{3}$ and $\mathrm{ZrO}_{2}$ powders were varied in order to get optimum composition for the structure. The process similarly replicate the processing flow as shown in Figure 1. Table 2 shows the variation of composition to fabricate $\mathrm{Al}_{2} \mathrm{O}_{3}-\mathrm{ZrO}_{2}$ cutting tool.

Table 2. Composition to fabricate $\mathrm{Al}_{2} \mathrm{O}_{3}-\mathrm{ZrO}_{2}$ cutting tool

\begin{tabular}{cc}
\hline Sample & Composition \\
\hline $\mathbf{A}$ & $90 \mathrm{wt} \% \mathrm{Al}_{2} \mathrm{O}_{3}$ and $10 \mathrm{wt} \% \mathrm{ZrO}_{2}$ \\
$\mathbf{B}$ & $85 \mathrm{wt} \% \mathrm{Al}_{2} \mathrm{O}_{3}$ and $15 \mathrm{wt} \% \mathrm{ZrO}_{2}$ \\
$\mathbf{C}$ & $80 \mathrm{wt} \% \mathrm{Al}_{2} \mathrm{O}_{3}$ and $20 \mathrm{wt} \% \mathrm{ZrO}_{2}$ \\
\hline
\end{tabular}

\section{Machining Performance}

Further, the performance of cutting tool were tested in machining with AISI 1045. Cutting tool that possess maximum density and hardness were selected for the cutting trials. The tests were held by using CNC (Computer Numerical Control) Turning Machine with cutting parameters according to the Table 3 . Tool wear for each trial were measured by using optical microscope according to guidance ISO 3685 [20]. For each measurement, the images of worn cutting tool were captured using optical microscope to observe the wear mechanism. Figure 2(a) shows the cutting tool and tool holder used in this study. Figure 2(b) shows the machining setup with AISI 1045 workpiece. 
Table 3. Cutting parameter for machining test

\begin{tabular}{ll}
\hline Cutting Speed (m/min) & $200,250,300,350$ \\
Feed Rate (mm/rev) & 0.1 \\
Depth of Cut (mm) & 0.5 \\
\hline
\end{tabular}
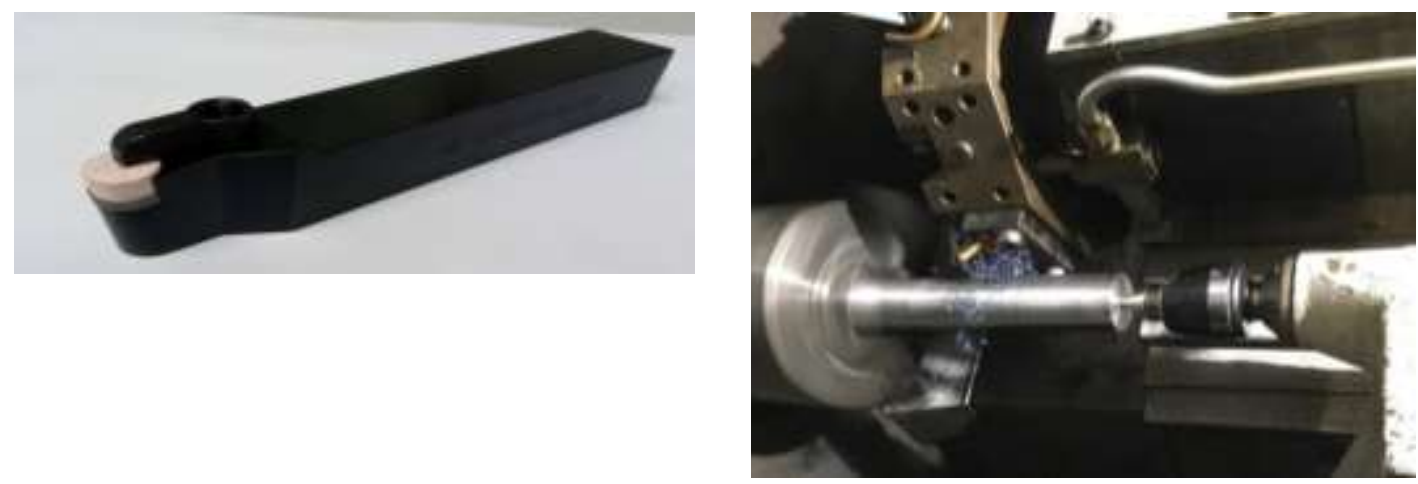

(a)

(b)

Figure 2. (a) Cutting tool with the design of RNGN120600 clamped in CRDN252543 tool holder (b) Machining setup with AISI 1045 work piece.

\section{RESULT AND DISCUSSION}

\section{Effect of Sintering Temperature on Hardness and Density}

Figure 3 shows the relationship between the relative density of $\mathrm{Al}_{2} \mathrm{O}_{3}-\mathrm{ZrO}_{2}\left(90 \mathrm{wt} \% \mathrm{Al}_{2} \mathrm{O}_{3}\right.$ and $10 \mathrm{wt} \% \mathrm{ZrO}_{2}$ ) that sintered with the various sintering temperature. It can be seen that the relative density of the $\mathrm{Al}_{2} \mathrm{O}_{3}-\mathrm{ZrO}_{2}$ ceramic increases as the sintering temperature increases in which the maximum relative density of $94.17 \%$ was recorded. In should be noted that the increment of density from $1200^{\circ} \mathrm{C}\left(73.91 \%\right.$ relative density) to $1400^{\circ} \mathrm{C}(94.17 \%$ relative density) consumed up to $28 \%$.

During sintering process, the energy from the heat sources initiated vibration of the atom of $\mathrm{Al}_{2} \mathrm{O}_{3}-\mathrm{ZrO}_{2}$ to initiate particle expansion. As the particles expanded toward grain boundary, the particles of $\mathrm{Al}_{2} \mathrm{O}_{3}$ would started to engage $\mathrm{ZrO}_{2}$ and yield diffusion to each other [21-22]. The reduction of porosity occurred during the diffusion process which leads to more compact and dense $\mathrm{Al}_{2} \mathrm{O}_{3}-\mathrm{ZrO}_{2}$ structure [23-24]. In the structure that contained large size of alumina particles and smaller size of zirconia particles, the high rate expansion of zirconia would inhibited the grain growth of alumina resulting controlled grain size of dominant alumina particles [25-26]. 


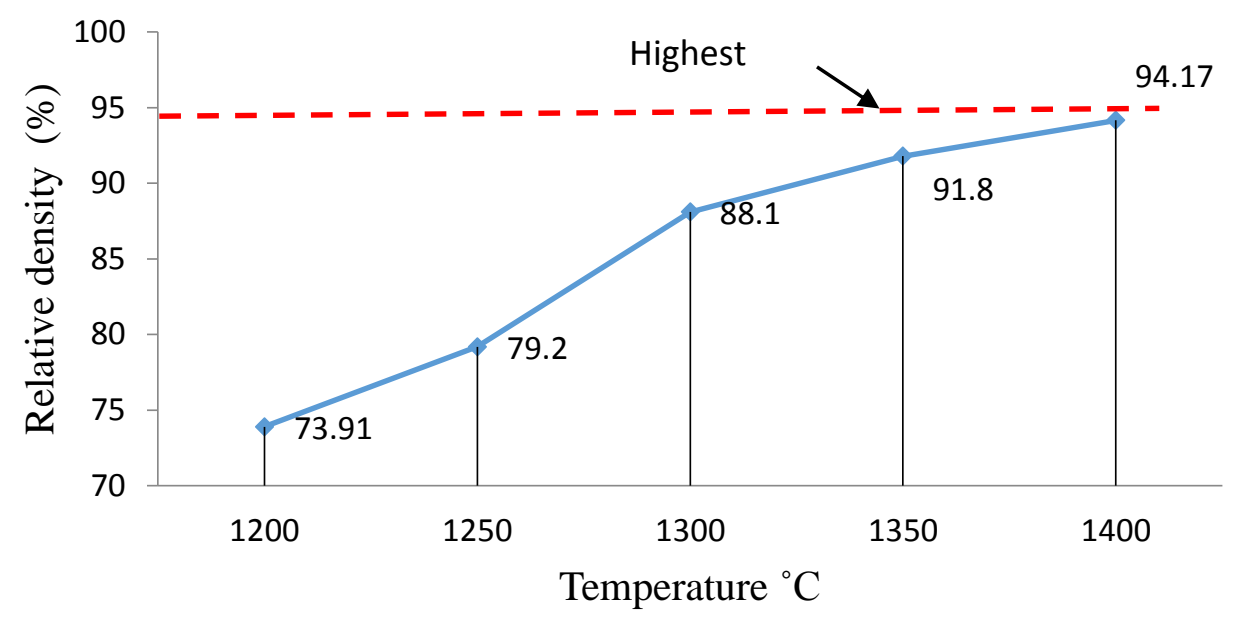

Figure 3. The effect of sintering temperature on relative density for $90 \mathrm{wt} \% \mathrm{Al}_{2} \mathrm{O}_{3}-10 \mathrm{wt} \%$ $\mathrm{ZrO}_{2}$ sample

Figure 4 shows effect of the sintering temperature on hardness based on the Rockwell scale (HRC). The plot clearly show that the hardness of $\mathrm{Al}_{2} \mathrm{O}_{3}-\mathrm{ZrO}_{2}$ compacts increased as the sintering temperature increased. At $1200^{\circ} \mathrm{C}$, hardness is at its lowest of $36 \mathrm{HRC}$ and can be classified as the weakest. Sintering $\mathrm{Al}_{2} \mathrm{O}_{3}-\mathrm{ZrO}_{2}$ compacts at this temperature reflected the particles still not adequately expanding to achieve full density. The gap that appeared between grains as a result of porosity facilitates deformation during hardness indentation test, resulting a low hardness value. The sequence temperature $1250^{\circ} \mathrm{C}, 1300^{\circ} \mathrm{C}, 1350^{\circ} \mathrm{C}$ and $1400^{\circ} \mathrm{C}$ shows a significant improvement of hardness with increasing to $42 \mathrm{HRC}, 49 \mathrm{HRC}$, $57 \mathrm{HRC}$ and $63.4 \mathrm{HRC}$ respectively. At $1400^{\circ} \mathrm{C}$ temperature is seen the most stable temperature in developing ceramic cutting tools.

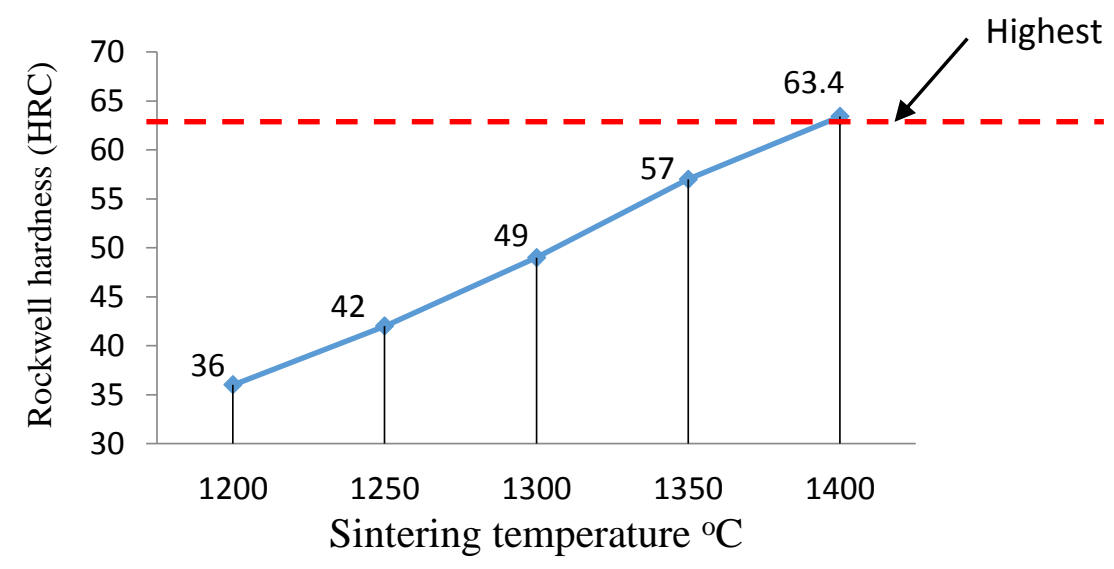

Figure 4. Effect sintering temperature on hardness for $90 \mathrm{wt} \% \mathrm{Al}_{2} \mathrm{O}_{3}-10 \mathrm{wt} \% \mathrm{ZrO}_{2}$ sample

Hardness can be defined as the ability of the structure to resist deformation from the designated load [27]. As the $\mathrm{Al}_{2} \mathrm{O}_{3}-\mathrm{ZrO}_{2}$ particles expanded during sintering, the engagement of these particles at the grain boundary could initiate diffusion between particles. Toughening transformation of between particles may take place which could initiating interlocking mechanism that can reinforce the structure [28-29]. On the same time, the contact area 
between particles being larger resulting stronger surface attraction force on the bond between the particles [30]. Such condition not only can enhance the ability of the particles to hold strong their surrounding matrix but also resist deformation whenever the load applied.

\section{Effect of $\mathrm{ZrO}_{2}$ on Hardness and Density}

Figure 5 shows effect of $\mathrm{ZrO}_{2}$ content of the relative density, with refer to $3.96 \mathrm{~g} / \mathrm{cm}^{3}$ as ideal density of $\mathrm{Al}_{2} \mathrm{O}_{3}$. These cutting tools were sintered at $1400^{\circ} \mathrm{C}$ and 9 hours soaking time. Clearly, the addition of $20 \mathrm{wt} \%$ of $\mathrm{ZrO}_{2}$ to the $80 \mathrm{wt} \% \mathrm{Al}_{2} \mathrm{O}_{3}$ contributed to maximum relative density of $97 \%$. This is folowed by $94 \%$ and $93 \%$ when $15 \mathrm{wt} \% \mathrm{ZrO}_{2}$ and $10 \mathrm{wt} \% \mathrm{ZrO}_{2}$ were added into the $\mathrm{Al}_{2} \mathrm{O}_{3}$ structure. Hardness evaluation also presented similar trend where the addition of $20 \mathrm{wt} \%$ of $\mathrm{ZrO}_{2}$ into the $80 \mathrm{wt} \% \mathrm{Al}_{2} \mathrm{O}_{3}$ contributed maximum hardness up to $70.07 \mathrm{HRC}$. This is $8 \%$ and $10 \%$ better than $15 \mathrm{wt} \% \mathrm{ZrO}_{2}$ and $10 \mathrm{wt} \% \mathrm{ZrO}_{2}$ addition into the $\mathrm{Al}_{2} \mathrm{O}_{3}$ structure.

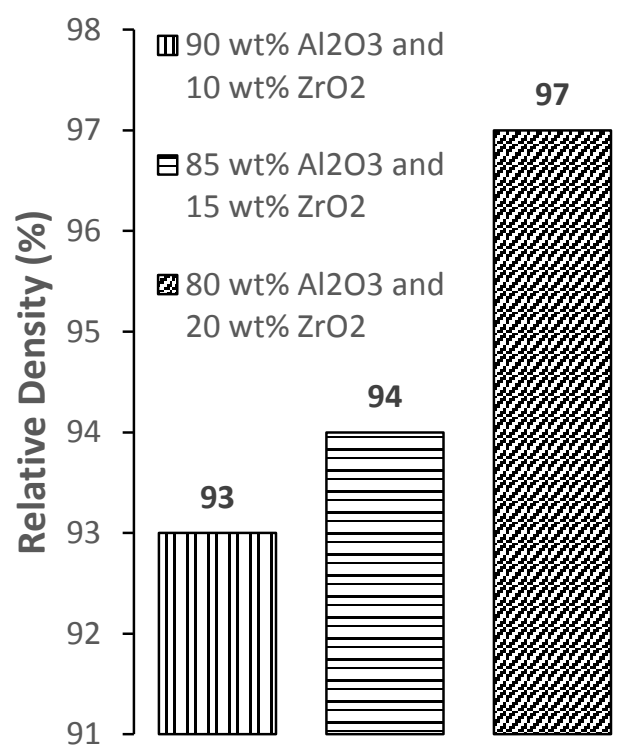

(a)

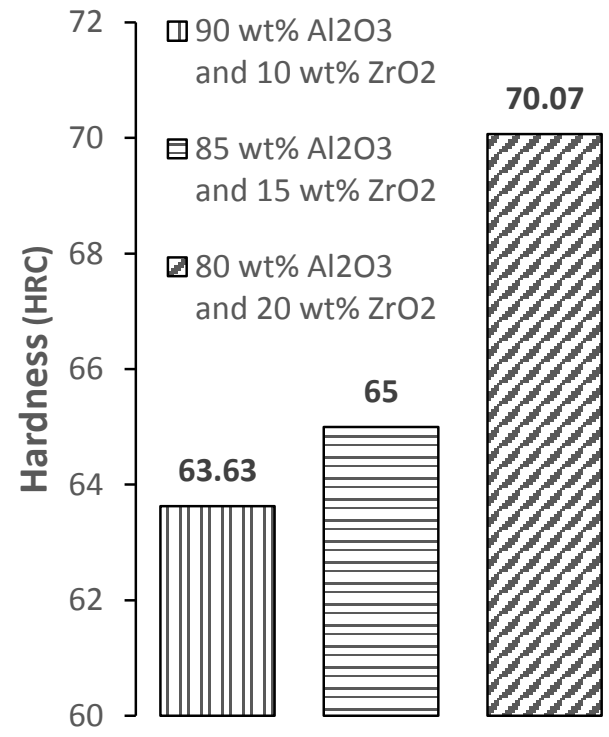

(b)

Figure 5. (a) Effect of $\mathrm{ZrO}_{2}$ content on relative density (b) Effect of $\mathrm{ZrO}_{2}$ content on harndess

The total denstiy of $\mathrm{Al}_{2} \mathrm{O}_{3}-\mathrm{ZrO}_{2}$ strongly independent on the $\mathrm{ZrO}_{2}$ weight content [31]. Since the density of $\mathrm{ZrO}_{2}$ consumed up to $5.68 \mathrm{~g} / \mathrm{cm}^{3}$ [23], more $\mathrm{ZrO}_{2}$ content should increased density to the $\mathrm{Al}_{2} \mathrm{O}_{3}$ structure. However it should be noted that addition of $20 \mathrm{wt} \%$ zirconia contributed to the $3.2 \%$ and $4.3 \%$ increment of density as compared to the addition of $15 \mathrm{wt} \% \mathrm{ZrO}_{2}$ and $10 \mathrm{wt} \% \mathrm{ZrO}_{2}$. This show that $20 \mathrm{wt} \%$ adequately enough to well dispersed along $\mathrm{Al}_{2} \mathrm{O}_{3}$ particles to provide optimum grain growth controll. When $\mathrm{ZrO}_{2}$ mixed with $\mathrm{Al}_{2} \mathrm{O}_{3}$ powders, the smaller particles of $\mathrm{ZrO}_{2}$ could trapped between larger $\mathrm{Al}_{2} \mathrm{O}_{3}$ particles. During sintering, the expansion of $\mathrm{ZrO}_{2}$ particles restricted the grain growth of alumina particles to produce uniform grain size [32-33]. Homogeneous uniform microstructure would give advantages for $\mathrm{Al}_{2} \mathrm{O}_{3}-\mathrm{ZrO}_{2}$ structure to provide less risks of stress concentration when experiencing high load and facilitate consistent wear rate during machining. 


\section{Machining Performance}

Since the cutting tool with $80 \mathrm{wt} \% \mathrm{Al}_{2} \mathrm{O}_{3}$ and $20 \mathrm{wt} \%$ zirconia demosntrated maximum density and hardness, these cuting tool were selected to be performed in machining operation. Figure 6 shows the wear performance of the fabricated cutting tools at a different cutting speed and constant $0.10 \mathrm{~mm} / \mathrm{rev}$ feed rate and $0.5 \mathrm{~mm}$ depth of cut. At the cutting speed of $200 \mathrm{~m} / \mathrm{min}$, the fabricated cutting tool recorded up to $156 \mathrm{~s}$ tool life. As the cutting seed increased to 250,300 and $350 \mathrm{~m} / \mathrm{min}$ respectively, the cutting tool performed at only $64 \mathrm{~s}$, $99 \mathrm{~s}$ and $112 \mathrm{~s}$ tool life respectively. This shows that the fabricated cutting tool in this study unable to perform effectively beyond the cutting speed of $200 \mathrm{~m} / \mathrm{min}$.

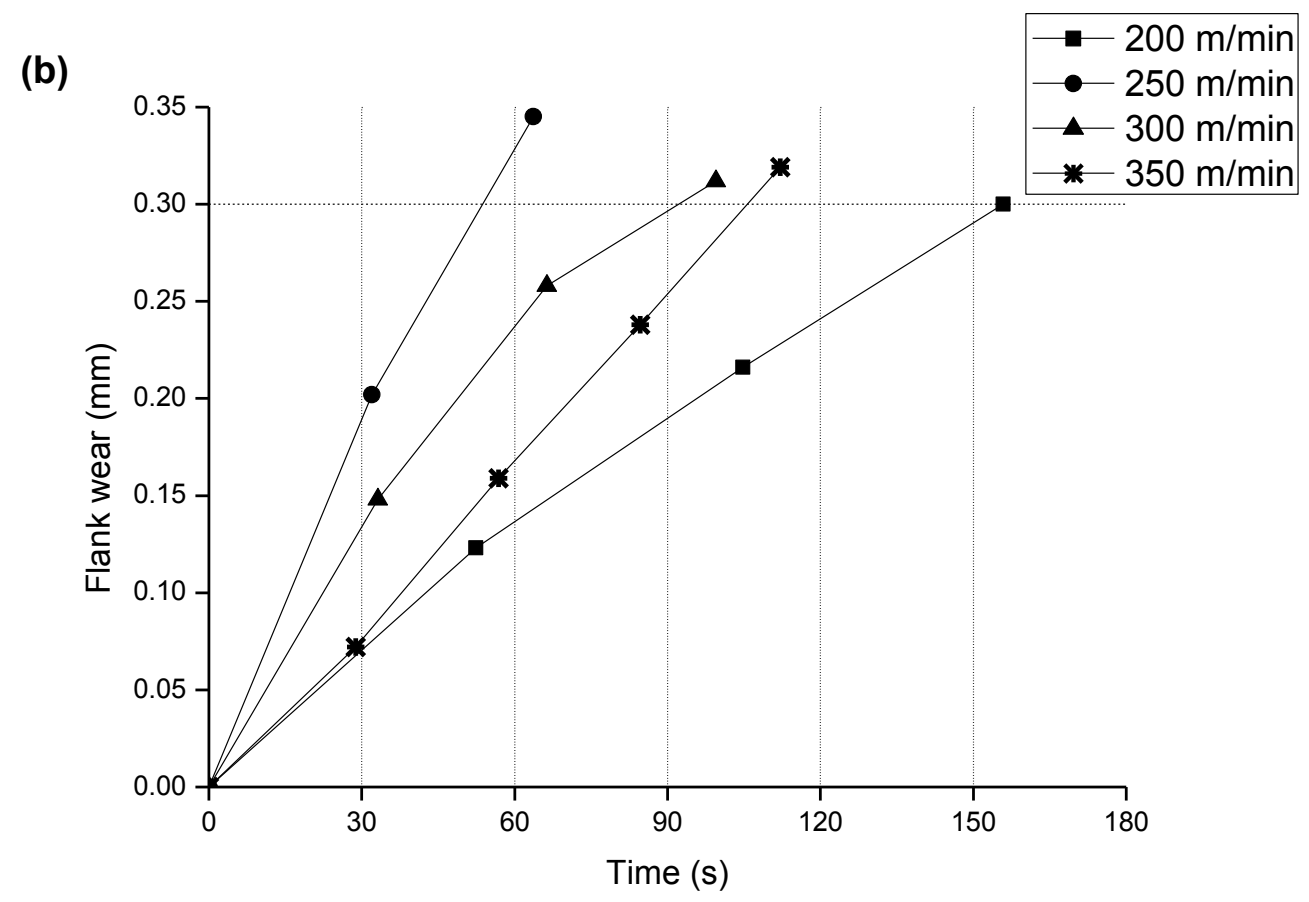

Figure 6. Values of flank wear at different cutting speed on feed rate $0.10 \mathrm{~mm} / \mathrm{rev} 80 \mathrm{wt} \%$ $\mathrm{Al}_{2} \mathrm{O}_{3}$ and $20 \mathrm{wt} \%$ zirconia

\section{Wear Mechanisme of $\mathrm{Al}_{2} \mathrm{O}_{3}-\mathrm{ZrO}_{2}$ Cutting Tool}

Further obervation of wear mechanisme of the fabricated cutting tools is shown in Figure 7. Only cutting tools that performed at $200 \mathrm{~m} / \mathrm{min}$ cutting speed were presented since these cutting tools recorded maximum tool life. Figure 8(a) shows that initial tool wear develop at the vicinity edge of cutting tool with minor formation of notch and flank wears. This shows that even though the $\mathrm{ZrO}_{2}$ already added into the $\mathrm{Al}_{2} \mathrm{O}_{3}$ sturcture, the wear formation demonstrated evidence of brittleness at the cutting edge. Further machining at $105 \mathrm{~s}$ presented stable wear that started to develop at the middle of flank area as shown in Figure 8(b). The are evidence of minor built up edge (BUE) as a sign of excessive heat generated [34]. BUE is a molten steel that attached at the edge of cutting tool as a result of high temperature and pressure during machining. The attacment of BUE resulting alteration of tool nose radius that can promote higher friction and subsequnetly cutting force [35-36]. As the machining prolonged to $156 \mathrm{~s}$, formation of BUE significantly appeared in the form of strong layer that 
attached on the worn surface as shown in Figure 8(c). Some portion of BUE could also diffused into the cutting tool to promote adhesive wear [37]. During machining, high temperature generation and pressure could yield welding formation at the joining asperity [38-39]. As the machining prolonged, the adherent welding area carried away the particles of the cutting tool as a result of rubbing counter bodies. Accumulation of material lost would result serious wear at the contact interfaces [40].

\begin{tabular}{|l|}
\hline Minor \\
formation \\
of notch \\
and flank \\
wears \\
\hline
\end{tabular}

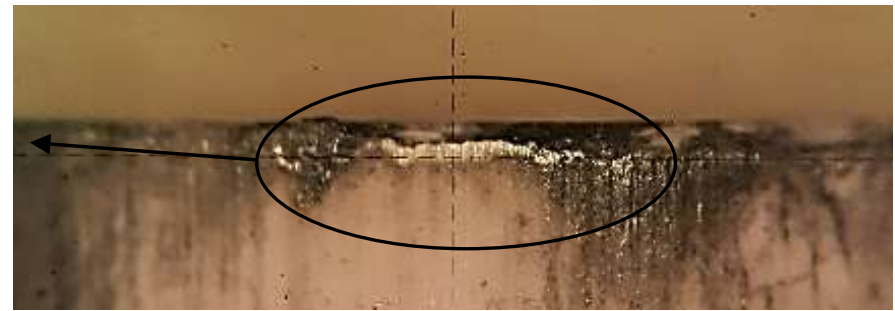

$0.12 \mathrm{~mm}$ wear after $52 \mathrm{~s}$ cutting time

$\begin{aligned} & \text { Wear } \\
& \text { started to } \\
& \text { develop at } \\
& \text { the middle } \\
& \text { of flank } \\
& \text { area }\end{aligned}$
\begin{tabular}{|l|}
\hline $\begin{array}{l}\text { Strong } \\
\text { layer of } \\
\text { BUE that } \\
\text { attached on } \\
\text { the worn } \\
\text { surface }\end{array}$ \\
\hline
\end{tabular}

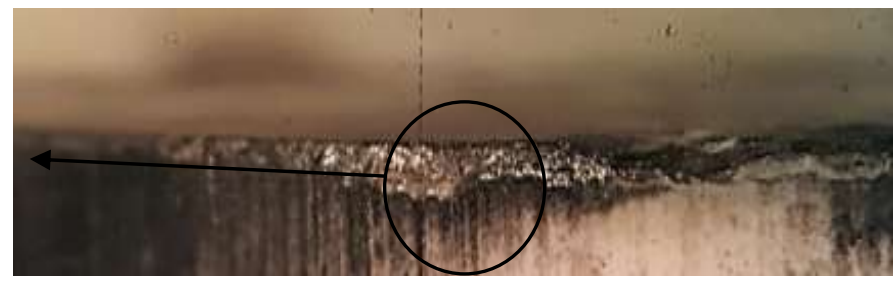

$0.22 \mathrm{~mm}$ wear after $105 \mathrm{~s}$ cutting time

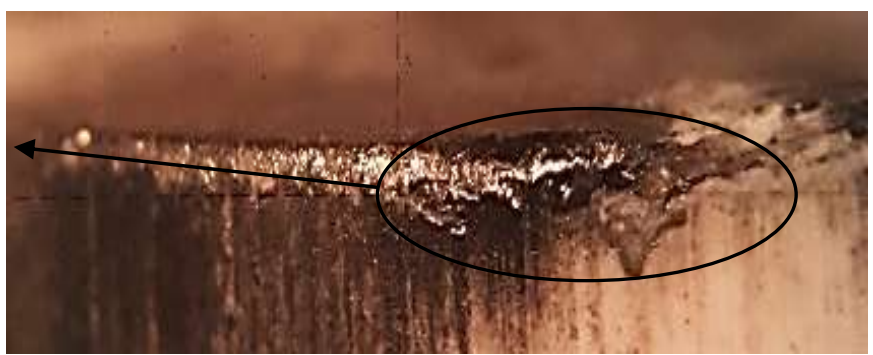

$0.12 \mathrm{~mm}$ wear after 156 s cutting time

Figure 7. Wear development of the cutting tool that contained $80 \mathrm{wt} \% \mathrm{Al}_{2} \mathrm{O}_{3}$ and $20 \mathrm{wt} \%$ $\mathrm{ZrO}_{2}$ at $200 \mathrm{~m} / \mathrm{mnin}$ cutting speed.

\section{CONCLUSION}

This paper presents the fabrication of ceramic cutting tool with various content of $\mathrm{Al}_{2} \mathrm{O}_{3}$ $\mathrm{ZrO}_{2}$ and sintered with different sintering temperature from $1200^{\circ} \mathrm{C}$ to $1400^{\circ} \mathrm{C}$. The properties of cutting tool have been analyses based on density and hardness. Selected cutting tools were machined with AISI 1045. Based on the experimental finding, the following conclusions can be drawn:-

- $\quad$ The relative density and hardness value of the cutting tool increased as the sintering temperature increased. Sintering temperature of $1400^{\circ} \mathrm{C}$ and 9 hours soaking time provided maximum relative density of $94 \%$ and hardness of $63 \mathrm{HRC}$. 
- $\quad$ Maximum density and hardness correlated with the diffusion and necking asperity of the grains between $\mathrm{Al}_{2} \mathrm{O}_{3}$ and $\mathrm{ZrO}_{2}$. This phenomenon providing porosity diminished and grains interlocking at the grain boundary.

- Maximum relative density and hardness of 97\% and $70.07 \mathrm{HRC}$ were obtained with combination of $80 \mathrm{wt} \%$ alumina and $20 \mathrm{wt} \% \mathrm{ZrO}_{2}$. Addition of $20 \mathrm{wt} \% \mathrm{ZrO}_{2}$ proven well dispersed to control grain growth of alumina.

- $\quad \mathrm{The} \mathrm{Al}_{2} \mathrm{O}_{3}-\mathrm{ZrO}_{2}$ cutting tool developed manage to perform up to $156 \mathrm{~s}$ tool life when machined with AISI 1045 at the cutting speed of $200 \mathrm{~m} / \mathrm{min}$, feed rate of $0.1 \mathrm{~mm} / \mathrm{rev}$ and depth of cut of $0.5 \mathrm{~mm}$. Cutting parameter beyond $200 \mathrm{~m} / \mathrm{min}$ demonstrated lower tool life.

- $\quad$ The wear formation for $\mathrm{Al}_{2} \mathrm{O}_{3}-\mathrm{ZrO}_{2}$ cutting tool started with the flank and notch wear at the early stage of machining before formation of the built of edge as the machine prolonged.

\section{ACKNOWLEDGEMENT}

The authors would like to thank Faculty of Manufacturing Engineering, Faculty of Engineering Technology and Universiti Teknikal Malaysia Melaka (UTeM) for their support that enabled this work to be carried out through the grant of FRGS/1/2017/TK03/FKPAMC/F00341.

\section{REFERENCES}

[1] Kanika P, Shankar C. A decision guidance framework for non traditional machining processes selection. Ain Shams Engineering Journal 2018;9(2):203-14.

[2] Izamshah, R, Zulhairy M, Kasim MS, Hadzley M, Amran M, Amri M, Sivaraos. Cutter Path Strategies for Shoulder Milling of Thin Deflecting Walls. Advanced Materials Research 2014;903:175-80.

[3] Kamely MA, Noordin MY, Hashim AYB, Yahya AY, Dan MMP. The Performance Of Low Cost Cutting Tools When Machining Hardened Steel Of 60 Hrc. Journal Of Advanced Manufacturing Technology 2012;6(1).

[4] Bakar MHA, Ahamd SSN, Abdullah RIR, Ali MAM, Kasim MS, Sulaiman MA, Raffi NFM. Evaluation of the Surface Integrity when Machining LM6 Aluminum Metal Matrix Composites Using Coated and Uncoated Carbide Cutting Tools. Applied Mechanics and Materials 2014;465:1049-53.

[5] Wang D, Xue C, Cao Y. Zhao J. Fabrication and cutting performance of an A12O3/TiC/TiN ceramic cutting tool in turning of an ultra-high-strength steel. The International Journal of Advanced Manufacturing Technology 2017;9:1967-76.

[6] Varaprasad B, Srinivasa RC, Vinay PV. Effect of Machining Parameters on Tool Wear in Hard Turning of AISI D3 Steel. Procedia Engineering 2014;97:338-45.

[7] Azhar AZA, Ratnam MM, Ahmad ZA. Effect of Al2O3/YSZ microstructures on wear and mechanical properties of cutting inserts. Journal of Alloys and Compounds 2009;478:608-14. 
[8] Hadzley AB, Naim F, Faiz Mokhtar M, Norfauzi T, Umar A, Aziz Adam A, Izamshah R, Kasim S. Fabrication and Machining Performance of Powder Compacted Alumina Based Cutting Tool. MATEC Web of Conferences 2018;150:04009.

[9] Mondal B, Mandal N, Doloi B. Development of Ce-PSZ-/Y-PSZ-Toughened Alumina Inserts for High-Speed Machining Steel. International Journal of Applied Ceramic Technology 2014;11:228-39.

[10] Manshor H, Abdullah EC, Azhar AZA, Sing YW, Ahmad ZA. Microwave sintering of zirconia-toughened alumina (ZTA)-TiO2-Cr2O3 ceramic composite: The effects on microstructure and properties. Journal of Alloys and Compounds 2017;722:45866.

[11] Azhar AZA, Choong LC, Mohamed H, Ratnam MM, Ahmad ZA. Effects of Cr2O3 addition on the mechanical properties, microstructure and wear performance of zirconia-toughened-alumina (ZTA) cutting inserts. Journal of Alloys and Compounds 2012;513: 91-6.

[12] Manshor H, Azhar AZA, Rashid RA, Sulaiman S,Abdullah EC., Ahmad ZA. Effects of $\mathrm{Cr} 2 \mathrm{O} 3$ addition on the phase, mechanical properties, and microstructure of zirconia-toughened alumina added with $\mathrm{TiO} 2$ (ZTA-TiO2) ceramic composite. International Journal of Refractory Metals and Hard Materials 2016;61:40-5.

[13] Vasudevan R, Karthik T, Ganesan S. Jayavel R. Effect of microwave sintering on the structural and densification behavior of sol-gel derived zirconia toughened alumina (ZTA) nanocomposites, Ceramics International 2013;39(3):3195-204.

[14] Manshor H, Md. Aris S, Azhar AZA, Abdullah EC, Ahmad ZA. Effects of TiO2 addition on the phase, mechanical properties, and microstructure of zirconiatoughened alumina ceramic composite. Ceramics International 2015;41:3961-67.

[15] Yin Z, Huang C, Yuan J, Zou B, Liu H, Zhu H. Cutting performance and life prediction of an $\mathrm{Al} 2 \mathrm{O} 3 / \mathrm{TiC}$ micro-nano-composite ceramic tool when machining austenitic stainless steel. Ceramics International 2015;41:7059-65.

[16] Szutkowska, M. Fracture Toughness of Advanced Alumina Ceramics and Alumina Matrix Composites Used for Cutting Tool Edges. Journal of Achievements in Materials and Manufacturing Engineering 2012;54:202-10.

[17] Azhar AZA, Mohamad H, Ratnam MM, Ahmad ZA. The effects of MgO addition on microstructure, mechanical properties and wear performance of zirconia-toughened alumina cutting inserts. Journal of alloys and compounds 2010;497:316-20.

[18] Singh BK, Mondal B, Mandal N. Machinability evaluation and desirability function optimization of turning parameters for $\mathrm{Cr} 2 \mathrm{O} 3$ doped zirconia toughened alumina $(\mathrm{Cr}-$ ZTA) cutting insert in high speed machining of steel. Ceramics International 2016;42:3338-50.

[19] Sabuan NA, Zolkafli N, Mebrahitom A, Azhari A, Mamat O. The development of Zirconia and Copper toughened Alumina ceramic insert. IOP Conference Series: Materials Science and Engineering 2018;342:012106.

[20] ISO 3685:1993 Tool-life testing with single-point turning tools.

[21] Vladimír P, David S, Karel M. Pressure-less rapid rate sintering of presintered alumina and zirconia ceramics. Ceramics International 2018;44(9),1084046. 
[22] Ji W, Parker B, Falco S, Zhang JY, Todd R. Ultra-fast firing : Effect of heating rate on sintering of 3YSZ, with and without an electric field. Journal of the European Ceramic Society 2017;37(6):2547-51.

[23] Cantwell PR, Ma S, Bojarski SA, Rohrer GS, Harmer, MP. Expanding timetemperature-transformation (TTT) diagrams to interfaces: A new approach for grain boundary engineering. Acta Materialia 2016;106:78-86.

[24] Meena KL, Karunakar DB. Development of alumina toughened zirconia nanocomposites using spark plasma sintering. Materials Today: Proceedings 2018;5(9):16928-35.

[25] Adriana SAC, Adilson LC, Christiane LO, Julieta AF, Elíria MJAP. Effect of sintering curves on the microstructure of alumina-zirconia nanocomposites. Ceramics International 2014;40(9):14669-76.

[26] Francisco ATG, Kátia LS, Vania T, Juliano JP, Eliria MJAP. Correlation between microstructure and mechanical properties of $\mathrm{Al} 2 \mathrm{O} 3 / \mathrm{ZrO} 2$ nanocomposites. Ceramics International 2009;35(2):741-45.

[27] Kuntz M., Krüger R. The effect of microstructure and chromia content on the properties of zirconia toughened alumina. Ceramics International, 2018;44:2011-20.

[28] Stephanie P, Pinar D, Rueya D, Heiko S, Michael RB. Synthesis of zirconia toughened alumina (ZTA) fibers for high performance materials. Journal of the European Ceramic Society 2016;36(3):725-731

[29] Bipin KS, Himadri R, Biswanath M, Sibendu SR, Nilrudra M. Development and machinability evaluation of $\mathrm{MgO}$ doped Y-ZTA ceramic inserts for high-speed machining of steel. Machining Science and Technology Singh 2018;1-15.

[30] Salam A, Saeed M, Elizabeth K, Andrew JR. Processing and Properties of ZirconiaToughened Alumina Prepared by Gelcasting. Materials 2015;8:4344-62.

[31] Valentina N, Paola P, Laura M., Jérôme C. Elaboration of Alumina-Zirconia Composites: Role of the Zirconia Content on the Microstructure and Mechanical Properties. Materials. 2013;6:2090-102.

[32] Norfauzi T, Hadzley AB, Umar UAA, Faiz MM, Naim MF, Aziz AA. Comparison machining performance of $\mathrm{Al}_{2} \mathrm{O}_{3}$, ZTA and ZTA doped $\mathrm{Cr}_{2} \mathrm{O}_{3}$ cutting tools on AISI 1045", Material Research Express 2019;6(1):016547.

[33] Milak PC, Minatto FD, De Noni Jr. A, Montedo ORK. Wear performance of aluminabased ceramics - a review of the influence of microstructure on erosive wear. Ceramica 2015;61:88-103.

[34] Azlan UAA, Hadzley M, Tamin NF, Noor FM, Azhar AA, Yusoff MR. Observation of Built-up Edge Formation on a Carbide Cutting Tool with Machining Aluminium Alloy under Dry and Wet Conditions. MATEC Web of Conferences 2017;97:01076.

[35] Atlati S, Haddag B, Nouari M, Moufki A. Effect of the local friction and contact nature on the Built-Up Edge formation process in machining ductile metals. Tribology International 2015;90:217-27.

[36] Gómez-Parra A, Álvarez-Alcón M, Salguero J, Batista M, Marcos M. Analysis of the evolution of the Built-Up Edge and Built-Up Layer formation mechanisms in the dry turning of aeronautical aluminium alloys Wear. 2013;302(1-2):1209-18.

[37] Da-Wang T, Wei-Ming G, Hong-Jian W, Hua-Tay L, Cheng-Yong W. Cutting performance and wear mechanism of TiB2-B4C ceramic cutting tools in high speed turning of Ti6A14V alloy. Ceramics International 2018;44(13):15495-502. 
[38] Kasim MS, Che Haron CH, Ghani JA,Sulaiman MA,Yazid MZA Wear mechanism and notch wear location prediction model in ball nose end milling of Inconel 718. Wear 2013;302(1-2):1171-79.

[39] Naskar A, Chattopadhyay AK Investigation on flank wear mechanism of CVD and PVD hard coatings in high speed dry turning of low and high carbon steel. Wear 2018;396-397:98-106.

[40] Sulaiman MA, Che Haron, CH, A Ghani J, Kasim MS. The study of wear process on uncoated carbide cutting tool in machining titanium alloy. Journal of Applied Sciences Research 2012;8(9):4821-27. 